\title{
PENGEMBANGAN KOMODITAS RUMPUT LAUT NUSA TENGGARA BARAT DENGAN MODEL HEXAGON UNTUK PEMBANGUNAN EKONOMI LOKAL
}

\section{Development of Seaweed Commodities in West Nusa Tenggara Using the Hexagon Model for Local Economic Development}

\author{
*Alfian Hidayat dan Purnami Safitri \\ Universitas Mataram, Indonesia \\ Jl. Majapahit No.62, Gomong, Selaparang, Kota Mataram, Nusa Tenggara Bar. 83115, Indonesia \\ Diterima tanggal: 11 Desember 2018 Diterima setelah perbaikan: 28 Maret 2019 \\ Disetujui terbit: 26 Juni 2019
}

\begin{abstract}
ABSTRAK
Rumput laut sebagai komoditas unggulan daerah NTB belum secara maksimal dikelola dengan baik. Potensi yang besar serta didukung dengan kultur masyarakat pesisir seharusnya mampu menjadikan komoditas rumput laut NTB berdaya saing tinggi. Kondisi permasalahan mendasar diatas kemudian menarik untuk diteliti dengan model Pembangunan Ekonomi Lokal (PEL) sebagai metode dalam melihat permasalahan yang ada. Penelitian ini menggunakan PEL model Hexagon dengan melihat dalam 6 dimensi terkait yakni target group, locational factors, policy focus and synergy, sustainability, governance serta planning. Hasil penelitian menemukan bahwa pemerintah daerah Provinsi NTB sesungguhnya telah memulai program Pembangunan Ekonomi Lokal, namun belum optimal dalam beberapa program yang telah dilakukan mulai dari pemilihan kelompok target yang disesuaikan dengan kapasitas industrial daerah, penyediaan sarana dan prasarana yang menunjang aktifitas ekonomi, keberhadiran kebijakan dan regulasi yang bersiat pro-environment dan pro-poor untuk mewujudkan prinsip pembangunan berkelanjutan, hingga pada upaya sinergisitas para stakeholders serta upaya monitoring dan evaluasi.
\end{abstract}

Kata Kunci: pembangunan ekonomi lokal (PEL); model hexagon; rumput laut NTB; daya saing

\section{ABSTRACT}

Seaweed, one of the competitive commodities in West Nusa Tenggara (NTB), has not been well governed. High potential value and coastal community culture are supposed to improve the competitiveness of the seaweed. Those conditions are the background of this research using Local Economic Development (LED) approach to describe the problems. LED has six dimensions of analysis; targeting group, location factors, policy focus and synergy, sustainability, governance and planning. This study found that NTB government has actually begun to implement LED dimension. However, there should be more optimal efforts to implement this program including selection of targeting group, development of infrastructure, pro-environment and pro-poor policy and regulation to support sustainable development, collaboration among stakeholders and monitoring and evaluation.

Keywords: local economic development; hexagonal model; seaweed; competitveness

\section{PENDAHULUAN}

Pembangunan Ekonomi Lokal (PEL) atau Local Economic Development sesungguhnya bukanlah konsep baru dalam studi pembangunan. Namun wacana mengenai pembangunan ekonomi lokal semakin menguat berkaitan dengan dampak globalisasi terhadap negara berkembang, terutama daerah (local regions). Globalisasi dianggap menantang konsep-konsep lama mengenai pembangunan ekonomi lokal, dimana dampak globalisasi kerap beragam terhadap negara ataupun daerah-daerah lokal. Sayangnya dampak utama dari globalisasi ini adalah semakin menajamnya kesenjangan dan peningkatan kemiskinan.

Persoalan globalisasi dan kemiskinan bukanlah persoalan yang dapat diurai secara sederhana. Pada satu aspek, globalisasi memang dikritik karena dampak yang ditimbulkannya. Dampak negatif globalisasi bahkan menjadi perdebatan tersendiri dalam studi pembangunan maupun globalisasi. Namun disisi yang lain, globalisasi pada kenyataannya bukanlah suatu proses yang sui generis dan dampak kesejahteraan merupakan suatu hal yang pasti dan otomatis 
terjadi. Artinya, kemiskinan dan kesenjangan bukanlah suatu dampak yang pasti ditimbulkan oleh globalisasi. Kemiskinan dan kesenjangan merupakan persoalan yang kompleks, terlebih jika dikaitkan dengan integrasi daerah atau regional dengan ekonomi global. Peningkatan kesenjangan dan kemiskinan di daerah dalam era globalisasi dapat disebabkan oleh beberapa hal, misalnya saja kapasitas daya saing, kapasitas inovasi, kapasitas kebijakan publik, dan lain sebagainya.

Dalam rangka merevitaliasi berbagai potensi perekonomian Provinsi Nusa Tenggara Barat (NTB). Pemerintah Provinsi NTB membuat terobosan baru melalui program-program unggulan, dalam rangka menjadikan provinsi NTB sebagai provinsi yang mampu merevitalisasi pertanian dengan baik, hal ini sejalan dengan program pemerintah nasional. Revitalisasi yang gencar dilakukan pemerintah NTB(BPS Provinsi Nusa Tenggara Barat, 2013) adalah pada sektor pertanian dan perternakan dalam artian luas yang mencakup tiga komoditas unggulan yakni sapi, jangung, dan rumput laut atau dikenal dengan program "PIJAR". Program ini dalam (BPS Provinsi Nusa Tenggara Barat, 2013) dilaksanakan dengan tujuan untuk meningkatkan pembangunan ekonomi, ketahanan pangan dan menurunkan tingkat pengangguran dan kemiskinan. Dengan adanya program PIJAR diharapkan mampu mendorong pembangunan ekonomi daerah, serta mampu menurunkan tingkat kemiskinan.Dalam perspektif $L E D$, peningkatan daya saing ataupun solusi pembangunan ekonomi harus didasarkan pada partisipasi dan sesuai dengan konteks lokalitas, baik kebutuhan, sumber daya maupun gagasan. Di Nusa Tenggara Barat, program LED mulai dikembangkan pada tahun 2012 yang merupakan program kerjasama antara pemerintah Jerman melalui badan kerjasama teknis (Germany Technical Cooperation-GTZ). Jalinan kerjasama ini mengarah pada pengembangan ekonomi lokal yang dikemas dalam Regional Economic Development (RED) di NTB (Antara, 2012). Basis utama GIZ-RED adalah merangkul mitra lokal dalam upaya pengembangan ekonomi daerah. Adapun tujuan GIZ-RED yakni memberi dukungan untuk meningkatkan kapasitas pemerintah daerah dalam melaksanakan prinsipprinsip tata pemerintahan yang baik melalui penerapan standar administrasi dan hukum untuk memenuhi kebutuhan masyarakat terkait desentralisasi pelayanan publik.

Dalam perspektif $L E D$, peningkatan daya saing ataupun solusi pembangunan ekonomi harus didasarkan pada partisipasi dan sesuai dengan konteks lokalitas, baik kebutuhan, sumber daya maupun gagasan. Di Nusa Tenggara Barat, program $L E D$ mulai dikembangkan pada tahun 2012 yang merupakan program kerjasama antara pemerintah Jerman melalui badan kerjasama teknis (Germany Technical Cooperation -GTZ). Jalinan kerjasama ini mengarah pada pengembangan ekonomi lokal yang dikemas dalam Regional Economic Development (RED) di NTB.Basis utama GIZ-RED adalah merangkul mitra lokal dalam upaya pengembangan ekonomi daerah. Adapun tujuan GIZ-RED yakni memberi dukungan untuk meningkatkan kapasitas pemerintah daerah dalam melaksanakan prinsip-prinsip tata pemerintahan yang baik melalui penerapan standar administrasi dan hukum untuk memenuhi kebutuhan masyarakat terkait desentralisasi pelayanan publik (Mataram AntaraNews, 2012).

Pemerintah NTB telah melakukan upaya upgrading guna meningkatkan daya saing komoditas rumput laut NTB. Beberapa bentuk upgrading yang dilakukan pemerintah NTB telah cukup baik namun masih belum mampu meningkatkan daya saing dikarenakan kendala kapabilitas kemampuan daerah. Lambannya upgrading juga menunjukkan bahwa peran pemerintah dinilai masih kurang dalam merealisasikan kebijakan pengembangan rumput laut. Kebijakan pengolahan rumput laut masih belum mengarah pada sektor indutri menengah, dan hanya sedkit dari persentase produksi yang berhasil ditingkatkanolehpemerintah NTB. Sedikitnya produk upgrading rumput laut yang secara kompetetif diluar pasar lokal menunjukkan bahwa kerjasama antara pemerintah dan industri rumput laut masih kurang. Hal ini ditunjukkan dengan tidak meratanya akses pasar yang didapatkan oleh masing-masing pelaku pengolah rumput laut.

Dalam Hidayat \& Safitri (2017) permasalahan utama pengembangkan komoditas unggulan rumput laut di NTB adalah masih minimnya penanganan pasca panen dan pengolahan hasil, rendahnya permodalan petani, serta terbatasnya kemitraan dalam pemasaran hasil. Untuk itu pemerintah perlu melakukan upaya-upaya strategis dalam upaya mendorong peningkatan nilai tambah hasil serta meningkatkan pendapatan dan kesejahteraan masyarakat/petani yaitu dengan membangun sarana pengolahan hasil rumput laut (pasca panen), jalinan kemitraan antara petani dengan investor serta penyediaan pasar fisik komoditas rumput laut guna memperluas peluang pengembangan usaha rumput laut. Pertama, petani pembudidaya masih 
menjadi aktor yang menerima cash-flowpaling rendah dalam rantai perdagangan rumput laut. Cash-flow yang rendah pada petani tidak saja disebabkan karena kurangnya pemahaman petani mengenai standarisasi rumput laut basah dan teknik untuk memproduksi rumput laut yang baik, namun juga disebabkan oleh rantai perdagangan yang cukup panjang sehingga tidak terbentuk strukturrantai nilai yang bersifat low-trust chain. Kedua, daya saing yang rendah mengakibatkan pola relasi yang asimetris antara buyer dan produsen. Petani bergantung pada pasar ekspor dan lebih memilih menjual hasil budidaya mereka untuk pasar ekspor. Hal ini dikarenakan harga jual yang dinilai lebih tinggi dibandingkan harga jual di pasar domestik. Ketergantungan pada pasar luar negeri menyebabkan posisi petani yang rentan karena keterbatasan daya saing. Ketiga, masih rendahnya sinergisitas para aktor terutama birokrasi. Birokrasi rumput laut masih dapat dikatakan tumpang tindih antara satu lembaga dengan lembaga lainnya. Dan terakhir, penyusunan peta jalan industrialisasi rumput laut masih bersifat sektor atau parsial. Hal ini tidak saja dilihat dari minimnya sinergisitas birokrasi, namun juga para stakeholder lainnya, serta sinergisitas kebijakan. Hal ini terlihat dari, misalnya upaya industrialisasi tidak diikuti dengan kebijakan harga, pembentukan networking atau jejaring global, dan efektifitas jejaring tingkat lokal yang meliputi pemerintah, petani, dan pedagang serta pelaku industri rumput laut.

Dari pemaparan mengenai rantai nilai rumput laut yang masih rendah dapat dilihat bahwadesentralisasi daerah merupakan suatu respon mengenai perlunya paradigma pembangunan yang bertumpu pada kebutuhan daerah. Hal ini dikarenakan setiap daerah memiliki keunikan masing-masing. Sehingga persepektif PEL dengan model HEXAGON dapat digunakan untuk menganalisis dan menelaah pengembangan industri rumput laut di NTB. Oleh karena itu, tulisan ini akan menjawab rumusan masalah, Bagaimana pengembangan komoditas rumput laut NTB dalam model HEXAGON pembangunan ekonomi local (PEL)?

\section{Metodologi dan Konsep LED (Local Economic Development)}

Heksagon PEL (pembangunan Ekonomi Lokal) atau LEDmenurut (Mayer \& Stamer, 2014) merupakan semacam alat didaktif. Tujuan model ini adalah menyusun dan sebagai pengingat isu-isu penting dalam proses pembangunan ekonomi lokal.
Model heksagon terdiri dari enam segitiga dimana masing-masing segitiga berkaitan dengan isu tertentu. Meski demikian, keenam segitiga ini tidak diartikan sebagai suatu runtutan aktifitas, namun hanya bersifat penggolongan isu-isu esensial dalam LED. Segitiga pertama dan kedua (target group dan locational factors) disebut sebagai instrumen inti LED. Segitiga ketiga dan keempat (policy focus and synergy dan sustanaibility) merupakan inovasi dan perluasan cakupan dan perspektif LEDyang disebut instrumen inovasi. Segitiga kelima dan keenam (governance dan planning $M+E$ ) mengenai isu-isu yang terkait dalam implementasi $L E D$ dan digolongkan sebagai segitiga koordinasi.

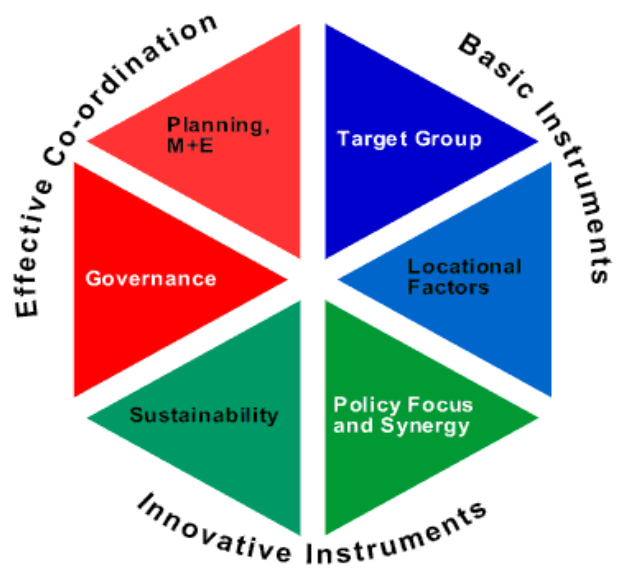

Gambar 1. PEL Model Hexagon. Figure.1 LED Hexagon Models.

Model pengembangan PEL juga telah menjadi rekomendasi kebijakan di beberapa daerah di Indonesia. Publikasi (Saragih, 2012) yang berjudul "Model Pengembangan Ekonomi Lokal (PEL) berbasis Kopi Arabika Spesialti di Kabupaten Simalungun" menguraikan beberapa strategi peningkatan produktifitas kopi melalui rekomendasi model PEL. Argumen (Saragih, 2012) menyatakan bahwa, teori PEL mengungkapkan pentingnya kolaborasi berbagai sektor dalam upaya peningkatan produktifitas kopi.

Adapun tulisan ini merupakan analisa deskriptif dengan menggunakan pendekatan kualitatif. Tulisan kualitatif lebih menekankan analisisnya pada proses penyimpulan deduktif dan induktif serta pada analisis terhadap dinamika hubungan antarfenomena yang diamati, dengan menggunakan logika ilmiahSedangkan untuk memperdalam pada konteks analisis pembangunan ekonomi lokal, digunakan indepth studi. Mengenai suatu unit sosial sedemikian rupa sehingga 
menghasilkan gambaran yang terorganisasikan dengan baik dan lengkap mengenai unit sosial tersebut (Azwar, 2007).

Pengembangan melalui teknik pengumpulan data dan output data yang diperoleh. analisis data menggunakan metode RALED (Rapid Assesment Techniques for Local Economic Development), dengan HexagonalPEL yang dimaksudkan untuk mengidentikasi secara cepat faktor pengungkit dari setiap aspek/dimensi PEL/komponen dari Heksagonal PEL, yang meliputi 1). Kelompok Sasaran, 2). Faktor Lokasi, 3). Kesinergian dan Fokus Kebijakan, 4). Pembangunan Berkelanjutan, 5). Tata Pemerintahan, dan 6). Proses Manajemen.

Berikut adalah "model interaktif" yang digambarkan oleh Miles dan Huberman, dalam (Sugiyono, 2012).

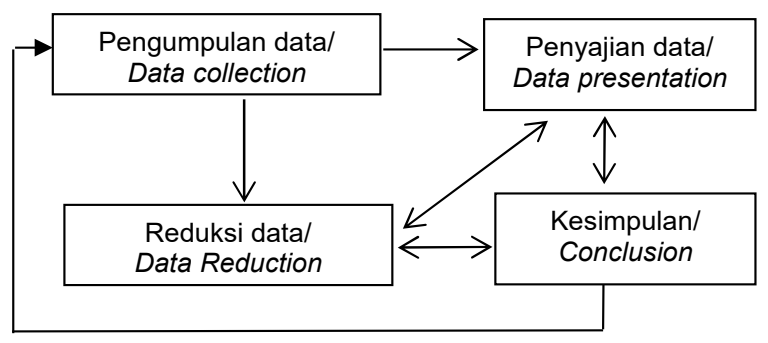

Gambar 2. Kerangka Analisa Data. Figure.2 Data Analysis Framework.

Pada tulisan ini unit-unit yang dimaksud adalah sinergitas diantara aktor-aktor pemerintah dalam hal ini Pemprov. NTB (dinas terkait), masyarakat petani rumput laut dan masyarakat sekitar wilayah lumbung rumput laut dan swasta yakni industri pengolahan. Dengan menggunakan metode kualitatif, maka data yang didapat akan lebih lengkap, lebih mendalam, kredibel, dan bermakna sehingga tujuan tulisan ini dapat dicapai.

\section{Pengembangan Rumput Laut NTB}

Dengan kontur geografisnya, NTB memiliki sumber daya alam yang melimpah. Selain sektor pertanian, pendapatan daerah wilayah ini juga ditopang oleh sektor pertambangan, perkebunan, dan pariwisata. Namun, pengembangan sektor kelautan dan perikanan untuk menjadi prime mover pembangunan ekonomi di NTB dipandang lebih tepat, mengingat potensi kelauatan yang dimiliki NTB juga melimpah. Potensi laut atau ekonomi perairan tidak saja didasarkan pada pertimbangan luasnya wilayah laut dan perairan yang dimiliki wilayah ini, namun juga provinsi NTB diberkahi oleh ekosistem perairan yang lengkap dan potensial bagi pengembangan sektor kelautan dan perikanan, misalnya saja NTB selain memiliki laut pelagis, juga memiliki laut demersal dengan ekosistem pesisir dan pulau-pulau kecil yang kaya akan terumbu karang, pada lamun dan mangrove. Tak kalah pentingnya, wilayah perairan laut NTB dapat dikatakan subur dan relatif bebas dari pencemaran.

Tantangan untuk membangun daerahnya secara mandiri, mendorong pemerintah daerah menciptakan program-program dan kebijakankebijakan pembangunan daerah sesuai dengan potensi unggulan daerahnya. Salah satu potensi unggulan yang dikembangkan oleh pemerintah provinsi NTB adalah rumput lautyang dikembangkan melalui Program Pijar (Sapi, Jagung dan Rumput Laut). Ketiga komoditas tersebut merupakan komoditas unggulan NTB.

Pengembangan rumput laut sebagai salah satu komoditas unggulan NTB tidak saja didasarkan pada aspek keunggulan wilayah namun juga sesuai dengan visi pembangunan nasional Presiden Jokowi tentang kedaulatan laut dan laut sebagai pilar masa depan Indonesia. Visi ini kemudian mendorong lahirnya strategistrategi pengembangan dan pembangunan blue economy atau ekonomi maritim yang memanfaatkan potensi laut dan perairan Indonesia.

Revolusi Biru yang ditetapkan berkontribusi positif terhadap rencana pengembangan komoditas unggulan laut NTB, yakni rumput laut. NTB kemudian ditetapkan menjadi salah satu sentra atau minapolitan pengembangan dan budi daya rumput laut. Hingga pada tahun 2001, ada sekitar 10 minapolitan atau sentra budi daya rumput laut di NTB. Tidak berhenti pada kesepuluh minapolitian tersebut, pemerintah terus gencar melakukan penelitian dan penginderaan untuk memindai daerah-daerah lain yang dianggap potensial sebagai sentra pengembangan budi daya rumput laut. Pada tahun 2012, total potensi areal budi daya rumput laut NTB sekitar 25 ribu hektar, dan pada tahun 2014 bertambah menjadi sekitar 30 ribu hektar, meningkat lagi menjadi 35 ribu hektar pada tahun 2016. Namun, pemanfaatan potensi areal tersebut hanya berkisar 30 hingga 50 persen saja, yang dikonsenterasikan di 10 minapolitan dapat dilihat pada Tabel 1. Hal ini patut disayangkan karena perluasan wilayah potensi budi daya ini ditujukan untuk meningkatkan produktifitas rumput laut NTB. 
Tabel 1 Luas Pemanfaatan Lahan Budi Daya Rumput Laut di 10 Minapolitan Tahun 2017. Table1 Total Area of Seaweed Cultivation in 10 Minipolitan Areas, 2017.

\begin{tabular}{lccc}
\hline \multicolumn{1}{c}{$\begin{array}{c}\text { Lokasi/ } \\
\text { Location }\end{array}$} & $\begin{array}{c}\text { Minapolitan/ } \\
\text { Minapolita area }\end{array}$ & $\begin{array}{c}\text { Potensi Luas Area } \\
\text { (Ha)/Potential area }\end{array}$ & $\begin{array}{c}\text { Pemanfaatan Area } \\
\text { (Ha)/ Area used }\end{array}$ \\
\hline Lombok Barat & Desa Pengantab & 2.900 & 600 \\
Lombok Tengah & Teluk Gerupuk & 1.200 & 200 \\
Lombok Timur & Teluk Ekas & 2.000 & 1.600 \\
& Teluk Sereweh & & 0 \\
Lombok Utara & Teluk Awang & 120 & 0 \\
Kota Mataram & & 0 & 2.300 \\
Sumbawa & Labuhan Mapin & 14.757 & 800 \\
Kec. Terano & Kuangko & 3.972 & 2.000 \\
Bimp & Wawaronda & 3.253 & 0 \\
Kota Bima & & 250 & 400 \\
Sumbawa Barat & \multicolumn{1}{c}{ Jumlah/Total } & 1.550 & $\mathbf{7 . 9 0 0 , 0 0}$ \\
\hline
\end{tabular}

Dikutip dari (Tri Sukmanto, wawancara pribadi, 2012, Agustus 2) dalam pemanfaatan lahan budi daya yang masih jauh dari potensi, produksi rumput laut NTB tetap mengalami peningkatan setiap tahun. Peningkatan produksi rumput laut NTB patutnya diapresiasi karena budi daya rumput laut telah memberikan kontribusi yang signifikan bagi perekonomian kelompok nelayan pembudi daya rumput laut. Harga rumput laut yang stabil dan jumlah permintaan yang terus mengalami peningkatan, membuat komoditas rumput laut yang relatif menguntungkan bagi petani. Selain harga dan permintaan yang stabil, budi daya rumput laut juga tidak membutuhkan teknologi yang rumit, dan membutuhkan perawatan yang sederhana dan murah.

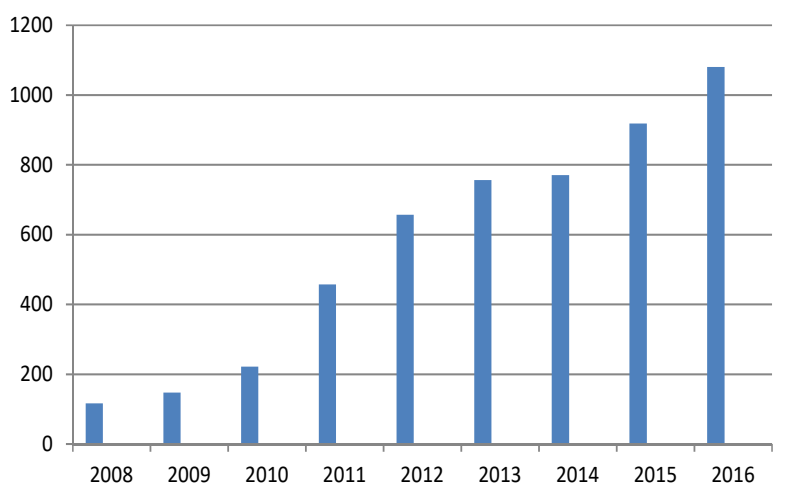

Gambar 3. Produktifitas Rumput Laut NTB 2008-2017. Figure 3. The Number of NTB Seaweed Productivity in 2008-2017.

Data menunjukkan bahwa produksi rumput laut menunjukkan peningkatan yang cukup signifikan. Menurut Dinas Kelautan dan Perikanan NTB misalnya, sejak tahun 2008 ada tren peningkatan produksi rumput laut NTB. Dari total produksi hanya mencapai 116 ton rumput laut basah menjadi 147 ton basah. Sejak pemerintah menetapkan Program Pijar pada tahun 2010, produksi rumput laut NTB meningkat hampir dua kali lipat, yakni mencapai hingga 221 ton dan sampai pada tahun 2016 peningkatan angka produk mencapai 1.037 ton.

Namun bertumpu hanya pada tingkat produksi dikhawatirkan akan membuat dampak ekonomi komoditas ini kurang berkesinambungan karena hanya terfokus pada kuantitas produksi, bukan diversifikasi atau proses penambahan nilai yang lebih menguntungkan bagi petani. Selama ini, Indonesia lebih menekankan pada aspek ekspor rumput laut mentah yang harganya sangat rendah dibandingkan dengan rumput laut yang telah berbentuk bubuk karaginan ataupun flakes. Ketiadaan kapasitas upgrading ini menyebabkan Indonesia secara umum dan NTB secara khusus berada pada rantai nilai yang paling rendah dalam struktur rantai nilai perdagangan global komoditas rumput laut. Dalam hemat penulis, keberlanjutan dampak dan manfaat komoditas rumput laut bertumpu pada kapasitas proses penambahan nilai atau upgrading. Ini berarti, baik Indonesia dan NTB yang menjadi fokus penelitian ini sepatutnya menginisiasi industrialisasi rumput laut. Namun demikian, industrialisasi rumput laut mensyaratkan banyak hal, misalnya saja akses terhadap kapasitas spesifik upgrading dan ketersediaan rente. Selain itu, juga diperlukan sinergi antara aktor yang terkait agar kebijakan sektor rumput laut bersifat integratif dan partisipatif. Ini artinya, pembangunan industrialisasi rumput laut haruslah disandarkan pada visi penguatan ekonomi lokal yang berbasis partisipasi komunitas dan nilai-nilai demokrasi. Pembangunan atau 
industrialisasi rumput laut tidak boleh mengorbankan kelompok marjinal dan komunitas petani, dengan demikian industrialisasi yang diidentikkan dengan monopoli dan monokultur pembangunan mesti diganti dengan visi partisipatif, setara dan demokrasi dimana aktor utama pembangunan adalah masyarakat sendiri. Secara sederhana, penulis hendak mengungkapkan bahwa rencana industrialisasi regional rumput laut dapat diperinci melakui analisa Pembangunan Ekonomi Lokal Model Heksagon.

\section{Hexagon Pembangunan Ekonomi Lokal Rumput Laut NTB}

Sebagaimana yang telah dipaparkan pada bagian sebelumnya, fokus utama dari perspektif LED adalah pembangunan yang bersifat partispatoris, berkelanjutan dan memiliki visi pengentasan kemiskinan. Ketiga aspek ini menuntut perencanaan dan pengelolaan pembangunan yang memastikan partsipasi masyarakat dalam setiap proses pembangunan, pemanfaatan sumber daya lokal secara maksimal yang juga ditujukan untuk memaksimalkan kemandirian ekonomi masyarakat dan pada akhirnya, proses pembangunan itu melibatkan berbagai sektor terutama lingkungan untuk menjamin keberlanjutan pembangunan ekonomi.

Dalam diagram heksagonal $\angle E D$, ada enam segitiga yang dapat dijadikan sebagai petunjuk sinergitas pertumbuhan dan keberlanjutan pembangunan itu sendiri. Analisis penelitian ini akan berusaha mengurai konten-konten setiap segitiga agar didapatkan pemahaman mengenai sejauh mana implementasi $L E D$ dalam pembangunan sektor rumput laut di NTB.

\section{Kelompok Target Pembangunan Ekonomi Lokal Sektor Rumput Laut.}

Secara teoritis, kelompok target kebijakan pembangunan ekonomi terdiri dari tiga (3) bentuk kelompok, yakni kelompok investor eksternal, perusahaan lokal, dan perusahaan start-up. Target prioritas ini sangat bergantung dari situasi dan kondisi suatu daerah. Penetapan kelompok target dalam $L E D$ berkaitan dengan proses industrialisasi suatu daerah. Sebagaimana yang telah dijabarkan dalam bagian rantai nilai perdagangan rumput laut NTB, terlihat permasalahan utama dari sektor rumput laut NTB adalah lemahnya industrialisasi rumput laut, baik itu dalam skala nasional maupun regional. Selama ini, NTB hanya mampu melakukan ekspor rumput laut dalam bentuk rumput laut kering mentah. Hal inilah yang menyebabkan ketergantungan sektor rumput laut, baik secara nasional ataupun regional terhadap perdagangan luar negeri. Padahal, pembangunan industri rumput laut dalam negeri dapat memacu serapan lokal terhadap rumput laut dan juga memacu perdagangan rumput laut pada sektor rumput laut olahan yang memiliki rantai nilai lebih tinggi dibandingkan dengan rantai nilai perdagangan rumput laut mentah.

Sektor industri rumput laut di NTB sesungguhnya masih di dominasi oleh kelompok industri kecil dan menengah. Kelompok industri ini memproduksi berbagai varian produk yang berbahan dasar rumput laut, misalnya dodol, manisan, sabun dan produk kosmetik lainnya. Beberapa kelompok industri memproduksi produk kosmetik untuk keperluan industri spa dan perhotelan. Meski memiliki potensi yang cukup baik, namun kelompok industri kecil dan menengah atau UMKM memiliki berbagai keterbatasan. Pada aspek yang bernilai positif, pengembangan UMKM dapat bernilai pada penguatan dan ketahanan ekonomi lokal maupun komunitas. Peran UMKM dalam menyerap tenaga kerja juga dianggap signifikan. Namun keterbatasan modal, pengetahuan, dan teknologi menyebabkan UMKM lamban berkembang dan tidak dapat diandalkan untuk menjadi penyerap pasar rumput laut lokal.

Dalam mendorong industrialisasi sektor rumput laut, pemerintah pun berinisiatif mengundang investor luar untuk mendirikan pabrik di NTB. Saat ini Pemerintah Daerah NTB tengah mengupayakan pembangunan pabrik kosmetik (berbahan dasar rumput laut) di daerah Banyumulek Lombok Barat. Selain itu juga upaya industrialisasi dilakukan oleh Dinas Koperasi dan UMKM dalam laporan evaluasi hasil pelaksanaan renja tahun 2015disebutkan beberapa kebijakan yang ditempuh oleh dinas untuk Pemberdayaan Koperasi dan UMKM, yakni 1) Pengembangan kewirausahaan dan UKM berkeunggulan kompetitif; 2) Menciptakan iklim usaha yang kondusif bagi pengembangan Koperasi dan UKM; 3) Meningkatkan akses Koperasi dan UKM pada sumber daya produktif; 4) Dukungan perkuatan bagi Koperasi dan UKM. Selain itu, untuk mewujudkan UMKM yang berdaya saing, pemerintah telah mengupayakan berbagai program yang terkait dengan peningkatan kualitas dan daya saing UMKM, misalnya saja penguatan lembaga kredit (koperasi) UMKM sebagai akses 
likuiditas, program kredit UKM, Bimtek, Program Rintisan Penerapan Teknologi sederhana, Diklat, fasilitas sertifikasi dan lain sebagainya. Selain penguatan kapasitas teknis dan produksi, juga diupayakan akses pasar bagi kelompok UMKM misalnya melalui pelatihan pemasaran, pengembangan sarana pemasaran melalui penyelenggaraan acara seperti Pasar Rakyat dan juga penyelenggaraan promosi produk UMKM melalui berbagai pameran (expo).

Dalam kerangka berfikir $L E D$, pertumbuhan big business yakni investor luar idealnya tidak boleh bersifat kontradiktif dengan upaya pembangunan dan penguatan ekonomi komunitas atau masyarakat. Pada aspek ini, pemerintah perlu mendesain kebijakan kemitraan industri antara industri kecil dan industri besar agar dapat tercipta relasi simbiosis mutualisme. Tentunya pemerintah tidak begitu saja mengandalkan pihak swasta atau bisnis namun juga harus mengupayakan berbagai insentif dan program yang dapat menarik minat pihak bisnis untuk berinvestasi.

\section{Faktor Lokalisional.}

Secara sederhana faktor lokalisional atau locational factor dapat diartikan sebagai faktorfaktor atau fitur-fitur yang menentukan apakah suatu daerah atau wilayah memenuhi kualifikasi bisnis (Edward, 1994) dalam bukunya Planning Local Economic Development menyatakan bahwa pembangunan ekonomi dan penciptaan lapangan kerja akan lebih berhasil dan efektif jika disesuaikan dengan kondisi dan potensi masingmasing wilayah atau komunitasDalam konteks yang sederhana, faktor lokalisional dapat berupa infrastruktur baik itu komunikasi, jalan, pelabuhan, proses perizinan yang transparan, cost business yang rasional, ketersediaan sumber daya, baik alam, manusia maupun energi, dan juga iklim usaha serta supporting industries, hingga pada aspek geografis. Secara geografis, NTB diberkahi kontur geografis dan bentang alam yang potensial bagi pengembangan ekonomi kelautan dan kemaritiman. Oleh karenanya, NTB menjadi salah satu daerah penghasil rumput laut terbesar di Indonesia. Faktor lokalisional memberikan kemudahan bagi kelompok industri dalam mengakses bahan baku. Kelimpahan bahan baku rumput laut di NTB dipandang sebagai faktor yang menarik minat para investor di Lombok.

Pada aspek infrastruktur, pemerintah NTB selama sepuluh tahun terakhir telah mengupayakan proyek pembangunan infrastruktur, mulai dari jalan, air dan listrik, komunikasi dan lain sebagainya. Pada tahun 2016 misalnya, capaian pembangunan jalan pemerintah Provinsi NTB telah mencapai 147,15 kilometer dengan 18 ruas jalan, dimana persentase kemantapan jalan nasional mencapai 100 persen dan 72,3 persen untuk jalan provinsi. Begitupula dengan listrik, NTB telah mengupayakan kecukupan energi listrik untuk menunjang geliat ekonomi yang semakin tumbuh.Selain itu, NTB juga telah membangun KEK Mandalika untuk mendorong pertumbuhan investasi dan juga pembangunan Global Hub yang akan menjadikan Lombok sebagai pusat perdagangan dan aktifitas ekonomi untuk Indonensia bagian Tengah dan Timur. Meski masih dalam proses groundbreaking, namun upaya pembangunan kota pelabuhan terintegrasi diharapkan dapat memunculkan keyakinan bahwa NTB sebagai kota industri masa depan.

\section{Aspek Keberlanjutan.}

Aspek keberlanjutan atau sustanaibility sesungguhnya menangkap sinergisitas antara aspek pembangunan ekonomi, sosial dan ekologi. Dengan demikian pembangunan yang berkelanjutan dapat diartikan sebagai inklusifitas pembangunan ekonomi dengan pembangunan sosial dan konservasi ekologi atau lingkungan. Dalam (Erlania \& Radiarta, 2015) budidaya rumput laut merupakan budidaya yang dapat dikatakan berbiaya rendah karena tidak membutuhkan biaya pemiliharaan yang tinggi, dan budidaya organic yang ramah lingkungan. Hal ini dikarenakan, budidaya rumput laut tidak membutuhkan pakan yang dapat meninggalkan residu organik yang dapat menyebabkan pencemaran di perairan. Sebaliknya, rumput laut dapat menyerap nutrien organik berupa nitrogen dan fosfor terlarut dari perairan dan dimanfaatkan untuk pertumbuhannya. Selain itu, rumput laut juga menyerap $\mathrm{CO} 2$ terlarut dari perairan, yang dikenal sebagai blue carbon, yang digunakan dalam proses fotosintesis.

Namun demikian, ada hal yang patut diperhatikan terkait budidaya rumput laut. Pertama, budidaya rumput laut bukanlah sektor yang bebas ancaman. Ancaman budidaya rumput laut terutama berasal dari organisme organic di perairan seperti jamur, virus ataupun ikan pemakan rumput (herbivorous fish). Ancaman terhadap rumput laut kerap menggoda petani untuk menggunakan produk-produk anti hama dan virus dalam proses budidaya rumput laut. Penggunaan zat anorganik atau kimia akan mengancam kesehatan perairan 
wilayah budidaya laut. Oleh karenanya, diperlukan suatu mekanisme untuk menjamin penerapan budidaya yang bertanggung jawab. Kedua, menurut Michael De san dalam (Soejarwo \& Fitriyanny, 2016) budidaya rumput laut haruslah memenuhi daya dukung perairan karena rumput laut sangat sensitif dan bergantung pada aspek lingkungan lokasi budidaya rumput laut. Pengaruh lingkungan yang berkaitan dengan kualitas perairan, pencemaran dan kondisi hidro-oseanografi mempunyai dampak yang besar terhadap usaha budidaya rumput laut.

Regulasi mengenai tata kelola wilayah perairan dan wilayah pesisir. Pada tingkat nasional peraturan atau undang-undangyang menjadi payung hukum peraturan daerah terkait lingkungan hidup adalah UU No 32 Tahun 2009 tentang Perlindungan dan Pengelolaan Lingkungan Hidup (UUPLH) dan UU No. 26 Tahun 2007 tentang Penataan Ruang. Sedangkan regulasi terkait kelautan dan wilayah pesisir yakni Undang-Undang Nomor 27 Tahun 2007 tentang Pengelolaan Wilayah Pesisir dan PulauPulau Kecil dan Peraturan Menteri Kelautan dan Perikanan Nomor 23/PERMENKP/2016 tentang Perencanaan Pengelolaan Wilayah Pesisir dan Pulau-Pulau Kecil dan Peraturan Menteri Kelautan dan Perikanan Nomor 47/PERMEN-KP/2016 tentang pemanfaatan kawasan konservasi perairan. Ditingkat daerah, pemerintah telah mengeluarkan regulasi mengenai penataan zonasi wilayah dan pengelolaan wilayah pesisir dan pulau-pulau kecil, yakni Peraturan Daerah Nomor 12 Tahun 2017 tentang Rencana Zonasi Wilayah Pesisir dan Pulau-Pulau Kecil dan Peraturan Daerah Nomor 2 Tahun 2008 tentang Pengelolaan Wilayah Pesisir dan Pulau-Pulau Kecil. Kedua regulasi tersebut kemudian menjadi landasan pemerintah daerah untuk menyusun Rencana Strategis Wilayah Pesisir dan Pulau-Pulau Kecil (RSWP3K), Rencana Zonasi Wilayah Pesisir dan Pulau-Pulau Kecil (RZWP3K), Rencana Pengelolaan Wilayah Pesisir dan PulauPulau Kecil (RPWP3K), Rencana Aksi Wilayah Pesisir dan Pulau-Pulau Kecil (RAKP3K) hingga pada perumusan rencana Zonasi Rinci.

Ruang partisipasi masyarakat dalam upaya penjagaan dan konservasi lingkungan menurut (Munara, 2018, Agustus 1) melalui pengakuan aturan adat atau awig-awig. Dipertegas oleh (Solihin \& Satria, 2007) Dalam beberapa kasus di daerah Lombok, penetapan aturan adat atau awig-awig oleh masyarakat berkaitan dengan kemunculan kesadaran bersama (collective consciousness) terhadap kerusakan lingkungan dan penurunan potensi ekonomi yang dialami masyarakat. Penetapan awig-awig memastikan hak wilayah laut masyarakat pesisir terhadap pemanfaataan sumber daya laut dan pesisir. Pengakuan awig-awig oleh pemerintah daerah merupakan perwujudan semangat demokratisasi ekonomi, prinsip desentralisasi dan otonomi serta visi pembangunan partisipatif.

Upaya merekonstruksi dan merivitalisasi awig-awig pada dasarnya telah dimulai sejak tahun 1994 oleh Pemerintah Desa Tanjung Luar, Keruak. Awig-awig masyarakat Tanjung Luar tersebut menetapkan "Jalur/Zona Penangkapan Ikan" bagi nelayan tradisional dan nelayan modern/semi modern. Aturan adat tersebut juga mengatur alat tangkap yang boleh digunakan kedua kelompok nelayan tersebut. Penggunaan alat tangkap yang merusak dilarang dan akan dikenakan sanksi. Namun pada waktu itu, tidak ada regulasi atau produk undang-undang yang mengakui eksistensi institusi lokal dalam upaya pengelolaan sumber daya laut maupun ikan karena pengelolaan pembangunan pada waktu itu masih menerapkan prinsip sentralisme, awig-awig tersebut pun tidak bisa dilembagakan dan tidak didokumentasikan. Undang-undang Nomor 22 Tahun 1999 yang berkaitan tentang desentralisasi pengelolaan sumber daya kelautan memberi angin segar bagi kelompok masyarakat untuk ikut berpartisipasi dalam pengelolaan sumber daya laut yang mereka miliki.

\section{Sinergi Pembangunan Ekonomi dan Pembangunan Sosial.}

Sinergisitas pembangunan ekonomi dan sosial dapat diwujudkan melalui visi pembangunan partsipatif dengan menitikberatkan pada pembangunan berbasis masyarakat (community based development) yang meletakkan masyarakat pada posisi strategis sebagai subyek dengan didukung upaya atau program-program pengentasan kemiskinan (poverty allevation) dan ketimpangan gender. Perempuan merupakan komponen penting dalam budi daya rumput laut. Hampir seluruh aktifitas budi daya rumput laut dikerjakan oleh perempuan, mulai dari pemasangan bibit pada longline, mengikat bibit hingga pada masa panen dan penjemuran. Mudahnya perempuan mengakses kerja budi daya rumput laut dikarenakan budi daya rumput laut tidak memerlukan teknologi yang rumit. Namun, budaya patriarki yang kuat dalam masyarakat pesisir mengancam perempuan karena membatasi perempuan untuk mengakses sumber daya 
ekonomi dan fasilitas budi daya rumput laut. Artinya, perempuan hanya berperan pendamping terhadap laki-laki.

Dalam situasi tertentu didapati juga kasus dimana perempuan berdaya secara ekonomi, dan perempuan menjadi aktor utama dalam budi daya rumput laut. Kepemilikian Iongline oleh perempuan dilatari oleh pemberian suami, sebagai bentuk tanggung jawab nafkah ekonomi. Pada aspek lain, suami justru memilih sektor lain seperti ternak untuk memenuhi ekonomi keluarga. Sesekali laki-laki berperan dalam rantai aktifitas budi daya rumput laut, yakni pada masa tanam karena harus menyelam dan mendayung untuk mengikat tali longline. Namun kasus ini bersifat tentative dan bukan representasi umum situasi sosiologis masyarakat pesisir.

Pemerintah telah berupaya membangun kemandirian masyarakat pesisir melalui berbagai program pemberdayaan misalnya dengan memberikan pelatihan untuk meningkatkan kapasitas pengolahan produk perikanan atau rumput laut, seperti dodol dan manisan. Tujuan dari program ini adalah agar petani pembudi daya dapat meningkatkan nilai produk komoditas rumput laut, dan diversifikasi rantai perdagangan rumput laut di kalangan petani rumput laut. Namun, program pemberdayaan ini tidak terdistribusi dengan baik. $\mathrm{Di}$ Teluk Sereweh misalnya, kelompok perempuan dan nelayan mengeluhkan kurangnya akses dan programprogram pemberdayaan ekonomi. Program-program pemberdayaan cenderung berupaproyek birokrasi tanpa ada komitmen yang kuat dari kelompok birokrasi. Program-program pemberdayaan kerap hanya terhenti pada proses pembuatan laporan tanpa ada kejelasan program lanjutan (follow-up).

\section{Aspek Tata Kelola (Governance).}

Segitiga governance dalam heksagon LED (Mayer \& Stamer, 2014) dan (Weisbrod, lynch, \& collin, 2004) berkaitan dengan sinergisitas sektor publik dan sektor privat atau kelompok pemerintah dan masyarakat. Sinergisitas antar kelompok aktor tidaklah selalu berbentuk lembaga atau organisasi, melainkan dapat berbentuk jaringan yang menghubungkan kelompok-kelompok aktor tersebut. Dalam konteks ini, setiap aktor dapat memiliki andil proses decision-making sehingga corak demokratis dapat lebih tercipta dalam proses pembangunan. Selain itu, tata kelola juga berkaitan dengan kontribusi dan sebaran tugas dan fungsi setiap aktor dalam jaringan pembangunan ekonomi lokal.

Model atau pola networking antara kelompok terkait dalam budidaya rumput laut belumlah matang ditataran pemerintahan daerah. Dalam perspektif $L E D$, aktor utama pembangunan ekonomi adalah pemerintah lokal atau pemerintah daerah, bukan pemerintah pusat. Hal ini terkait dengan motivasi memperkuat prinsip desentralisasi dalam perspektif LEDatau PEL. Ketiadaan panel atau forum $L E D$ merupakan salah satu persoalan yang dapat memicu disintegralisasi dan sinergisitas pembangunan ekonomi lokal. Persoalan ini pada dasarnya bermuara pada kurang kuatnya visi atau perspektif PEL yang dianut oleh pemerintah daerah. Jargon pembangunan lokal kerap terucap namun tidak didukung oleh kapasitas kelembagaan yang kuat. Hal ini terlihat misalnya saja terjadinya tumpang tindih tupoksi antara dinas yang satu dengan dinas lainnya. Misalnya saja mengenai pembangunan ekonomi rumput laut, mulai dari Bappeda, Dinas Perindustrian, Dinas Perdagangan, Dinas Koperasi dan UMKM hingga DKP memiliki bidang agroindustri rumput laut. Begitu pula dengan program pengentasan kemiskinan dan pemberdayaan rumput laut, yang dimiliki oleh Dinas Sosial, Bappeda, Dinas Koperasi UMKM dan Dinas Perindustrian.

Upaya sinergi birokrasi pada dasarnya telah diupayakan, dilihat dari adanya Lembaga Perencana dan Pengawasan seperti Bappeda. Bappeda dan SKPD memiliki jadwal rutin untuk sinergi kebijakan. Namun demikian, perlu diberikan catatan bahwa sinergi ini kerap bersifat birokratis dimana pertemuan antar lembaga terkait hanya pada ketika rapat rutin (business as usual). Padahal, Keberhadiran pelembagaan lokal atau forum konsultatif akan memudahkan pengawasan dan evaluasi kebijakan yang berkesinambungan. Dengan demikian, dapat dilihat bahwa pola sinergi atau relasi yang bersifat integral antara ketiga aktor tersebut belum cukup kuat dan belum cukup terlembaga.

\section{Aspek Manajemen.}

Aspek manajemen sesungguhnya berkaitan dengan kesadaran bahwa program Pembangunan Ekonomi Lokal sebagai suatu life-cycle, yang bisa dimulai namun tidak pernah usai. LED atau PEL berhadapan dengan target bergerak, dalam artian 
penyelesaian suatu masalah dalam lingkaran sektor, akan selalu ada identifikasi persoalan baru dan upaya pencapaian standar yang lebih baik.

Hal inilah yang menyebabkan kapasitas evaluasi dan pengawasan program $L E D$ sangat diperlukan dalam rangka pemenuhan prinsip good management.

Dalam sektor budi daya rumput laut, upaya monitoring dan evaluasi dilakukan oleh aktor pemerintah terkait dengan implementasi kebijakan dan program. Misalnya saja dinas-dinas terkait melakukan upaya diagnosis melalui penyusunan Rencana Strategis maupun Rencana Kerja, kemudian setelah program target dijalankan, baru disusun Laporan Evaluasi Kebijakan. Hal tersebut merupakan task dari kelompok birokrat. Namun jika menggunakan perspektif $L E D$, proses manajemen tersebut haruslah melibatkan berbagai aktor atau stakeholders, yang dapat digagas melalui pembentukan panel $L E D$. Namun sekali lagi, panel LED tersebut nampaknya belum dikelola secara maksimal, akibatnya upaya manajemen pun masih bersifat sektoral dan parsial.

Berikut gambaran pengembangan rumput laut dalam prespektif PEL terangkum dalam Gambar 4.

\section{PENUTUP}

Pengembangan komoditas Rumput Laut Di NTB belum optimal dalam pendekatan pembangunan ekonomi lokal. Beberapa hal diantaranya; aspek pertama targeting group, pemerintah NTB hanya berorientasi pada pembangunan big business dan minim dalam penguatan sektor mikro dan kecil dalam upaya pemberdayaan masyarakat pesisir dalam pengembangan rumput laut. Aspek kedua lokasional faktor, pengembangan rumput laut NTB masih belum optimal dibandingkan potensi area yang dimiliki, namun cukup tinggi dalam skala dan trend produksi di tingkat nasional. Aspek ketiga keberlanjutan, untuk mendukung pengembangan rumput laut pemerintah daerah NTB telah mendasain Blue Economy dengan regulasi yang mendukung pembangunan keberlanjutan pada pengembangan rumput laut, selain itu masyarakat lokal diberikan kemandirian dalam mengelola pengembangan rumput laut di wilayah mereka dengan hukum atau adat-istiadat yang dikenal dengan istilah awig-awig. Aspek keempat yakni sinergi pembagian ekonomi dan sosial. Pengembangan rumput laut NTB masih jauh dari konsep Fair Trade, akses petani ke pasar masih bergantung pada pengepul yang menjadikan nilai

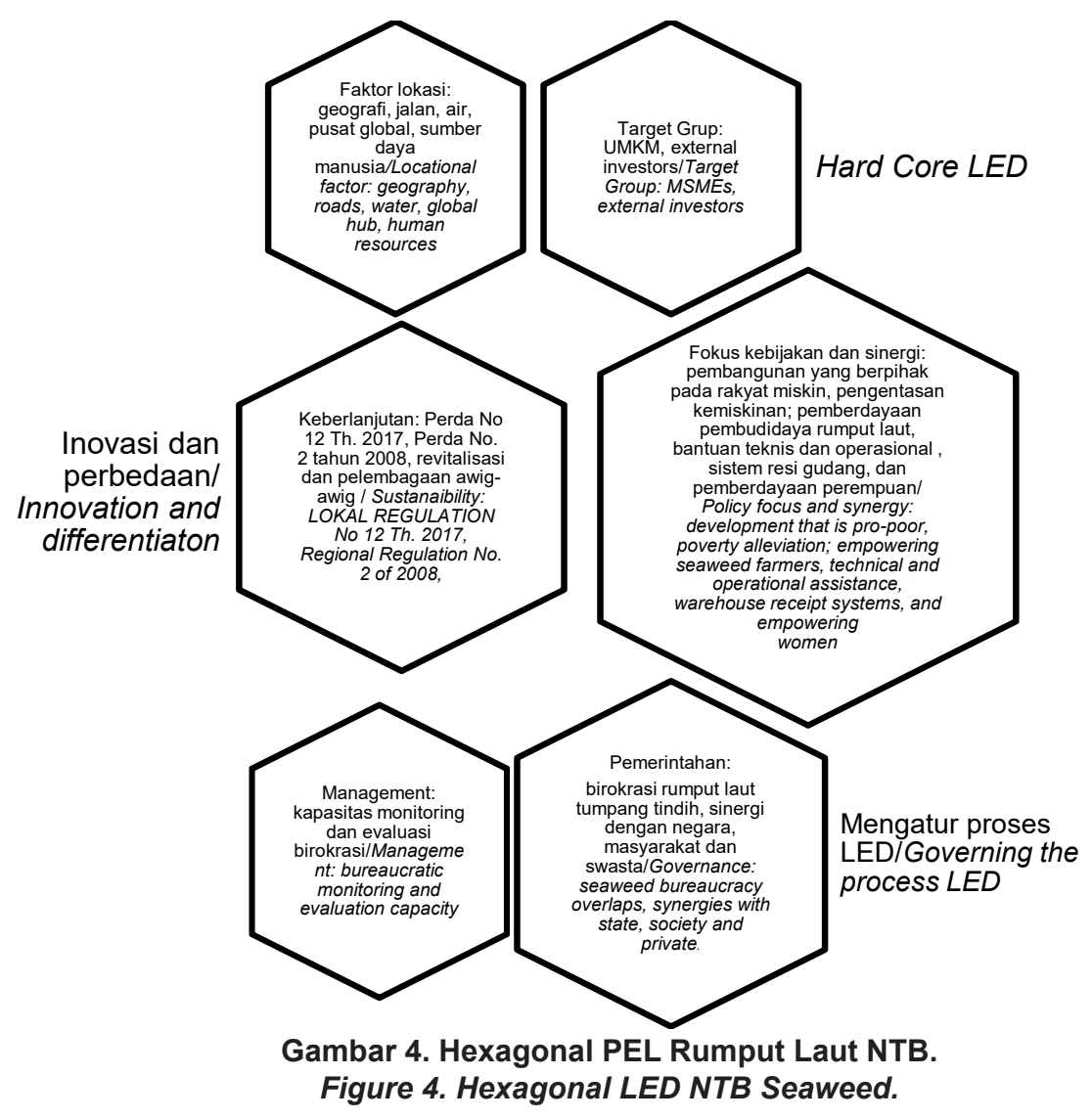


rumput laut belum mampu memberikan kontribusi yang besar pada pendapatan petani dan masyarakat pesisir, namun disatu sisi pengembangan rumput laut telah memberikan kesempatan pada wanitawanita untuk mendapatkan posisi pada mata rantai pengembangan rumput laut di NTB. Kelima aspek sinergitas aktor, pengembangan rumput laut di NTB memiliki masalah besar pada sinegitas diantara masyarakat, pemerintah dan swasta. Hal ini terlihat dari belum adanya kelembagaan yang menaungi aktor pengembangan rumput laut di NTB. Aspek keenam, yakni aspek manajemen, pengelolaan rumput laut di NTB belum sesuai dengan jargon PIJAR NTB yang menjadi komoditas unggulan di NTB. Monitoring dan evaluasi dalam kerangka pengembangan rumput laut masih bersifat parsial dan belum tepat sasaran.

Selian itu ada beberapa hal yang menjadi perhatian pengembangan komoditas rumput laut dalam prespektif PEL yakni pertama aspek overlapping bureaucracy yakni masih terjadinya tumpang tindih tupoksi antara satu dinas dan dinas lainnya. Satu program sejenis dapat dijalankan oleh beberapa dinas atau lembaga. Hal ini menyebabkan fokus kebijakan dan sinergi kebijakan tidak berjalan optimal karena ada semacam perebutan arenakerja. Kedua, pemerintah belum membentuk suatu panel atau forum yang menjadi wadah konsultasi dan pertukaran informasi dengan kelompok-kelompok terkait dalam sektor rumput laut. ketiga, kebijakan pro-poor serta pemberdayaan komunitas dan kelompok perempuan belum digarap secara maksimal. Program pemberdayaan dan pengentasan kemiskinan kerap bercorak bureaucrat project tanpa adanya visi dan komitmen yang kuat. Hal ini pun menyebaban diskontinuitas program-program pengentasan kemiskinan dan pemberdayaan masyarakat. Keempat, aspek lingkungan mesti diperkuat tidak saja melalui regulasi namun pada aspek penindakan. Sinergi lingkungan dengan sektor industri lain juga diperlukan. Pemerintah perlu mengkaji dampak pariwisata, pelayaran dan industri pertambangan terhadap industri rumput laut.

\section{UCAPAN TERIMA KASIH}

Terima kasih kepada seluruh stakeholder pengembangan rumput laut pemerintah provinsi NTB serta perangkat desa serewa lotim beserta seluruh kelompok tani rumput laut di wilayah serewa lotim

\section{DAFTAR PUSTAKA}

Antara, B. (2012, November 28). Jerman Dukung Pengembangan Ekonomi Lokal Di NTB. Mataram, NTB, Indonesia. Retrieved April 9, 2018, From Berita Antara: Https://Mataram. Antaranews.com.

Azwar, S. (2007). Metode Penelitian. Yogyakarta, ID: Pusataka Pelajar.

Badan Pusat Statistik Provinsi Nusa Tenggara Barat. (2013). Analisis Rumah Tangga Komoditas Unggulan Daerah Nusa Tenggara Barat Hasil Sensus Pertanian. Mataram.

Bambang, B. (2005). Telaah Implementasi Kebijakan Local Economic Development (LED) di Jawa Tengah. Eko-Regional-Jurnal Pembangunan Ekonomi Wilayah

Bisnis Indonesia, (2017). Komoditas Ekspor :NTB Pacu Produksi Rumput Laut. Retraived From: https:// koran.bisnis.com/read/20170914/452/689684/ komoditas-ekspor-ntb-pacu-produksi-rumput-laut.

Edward, B. (1994). Planning Local Economic Development. California, USA: Sage Publications.

Erlania \& Radiarta, I. N. (2015). Pengembangan Budidaya Rumput Luat : Implikasi Penerpan Blue Economi di teluk Sereweh, NTB. Media Akukultur , 97-101.

Hidayat, S. \&Safitri, P. (2017). Analisis Rantai Nilai Komoditas Rumput Laut NTB. Mataram; repository unram.

Indonesia, R. (2007). UU No. 26 Tentang Penataan Ruang.

Indonesia, R. (2007). UU No.27 Tentang Pengelolaan Wilayah Pesisir Dan Pulau-Pulau Kecil.

Indonesia, R. (2009). UUNo 32. Jakarta.

Kicknew. (2009).Pembangunan Indfrasturktur Din NTB Terus Meningkat.Retrieved November 2018, From Kicknew: Http://Kicknew.

Mayer, D. \&J.Stamer. (2014). Sustaining Local Economic Development Initiative: Mesopartner.Retraived From: https://www.mesopartner.com/fileadmin/ media_center/Working_papers/mp-wp03_01.pdf.

NTB, P. (2017). Peraturan Daerah No 12 Tentang Rencana Zonasi Wilayah Pesisir Dan Pulau-Pulau Kecil.

Saragih, J. R. (2012). Model Pengembangan Ekonomi Lokal (PEL) Berbasis Produktivitas Kopi Arabika Spesialti di Kabupaten Simalungun. Wahana Hijau: Perencanaan dan Pengembangan Wilayah.

Soejarwo, A. P., \& Fitriyanny, W. P. (2016). Pengelolaan Budidaya Rumput Laut Berkelanjutan Untuk Masyarakat pesisi Pulau Pajang Serang Banten. Jurnal Kebijakan Sosek KP , 123-134. 
Solihin, A. \& A. Satria. (2007). Hak Ulayat Di Era Otonomi Daerah Sebagai Solusi Pengelolaan Perikanan Berkelanjutan: Kasus Awig-Awig. Transdisiplin, Komunikasi Dan Ekologi Manuisa. Sodality: Jurnal Sosiologi Pedesaan,67-68.Retrieved from:http://journal.ipb.ac.id/index.php/sodality.

Sugiyono. (2012). Metode Penelitian Kuantitatif Kualitatif dan R\&D. Bandung, ID: Afabeta.

Weisbrod, G., T. Lynch \&M. Collin. (2004). Handbook: Assessing Local Economic Development Oppurtunities With Arc-Leap.Washington DC, USA : Appalachian Regional Commission. 